\title{
PENGARUH PENYULUHAN KESEHATAN TERHADAP PENGETAHUAN SISWA TENTANG PANGAN JAJANAN ANAK SEKOLAH
}

\author{
Siti Muniroh \\ Prodi D-III Keperawatan Fakultas Ilmu Kesehatan Unipdu Jombang
}

\begin{abstract}
ABSTRAK
Anak-anak yang kuat, sehat dan cerdas merupakan penentu keberlangsungan bangsa Indonesia. Salah satu faktor penting yang menentukan hal tersebut adalah jumlah asupan gizi yang mampu memenuhi kecukupan gizi. Di Indonesia saat ini, anak-anak mengalami masalah gizi ganda yaitu kekurangan gizi dan kelebihan gizi. Sehingga diperlukan upaya untuk mengatasi hal tersebut, diantaranya adalah penyuluhan kesehatan agar tertanam pola hidup sehat sejak dini. Penelitian ini bertujuan untuk mengetahui pengaruh penyuluhan kesehatan terhadap pengetahuan siswa tentang pangan jajanan anak sekolah. Desain penelitian ini adalah Quasy Eksperiment dengan rancangan Pretest - Postest Control Group. Jumlah sampel dalam penelitian adalah 95 responden, teknik pengambilan sampel simple random sampling. Tempat penelitian di MI Alhidayah Peterongan Jombang. Instrumen yang digunakan kuesioner. Uji yang digunakan Wilcoxon dan Mann Whitney. Hasil penelitian ini bahwa $\rho=0,000$ yang artinya ada pengaruh penyuluhan kesehatan terhadap pengetahuan siswa tentang pangan jajanan anak sekolah. Penyuluhan kesehatan merupakan salah satu upaya untuk meningkatkan pengetahuan tentang kesehatan sehingga tercapai derajat kesehatan yang optimal.
\end{abstract}

Kata Kunci: Pangan Jajanan Anak Sekolah, Penyuluhan Kesehatan

\begin{abstract}
In terms of the selection of snacks, school age children still lack of in terms of safety and cleanliness. This can be occured they lack of knowledges safe snacks to be consumed. Health promotion is needed to instill healthy living habits to students'. The purpose of this research is to analyze the influences of health promotion using lecture method and a media of crossword puzzle to students' knowledges level about school snacks safety. This study used quasy experimental design with pretest - postest control group. The subjects of the research were 110 children for grade IV - V, this research also used questionnaire and crossword puzzle. It was analyzed usig the Wilcoxon test and Mann Whitney u-test. The results showed there were influences of health promotion using lecture method and a media of crossword puzzle to students knowledges about school snacks safety $(p=0,000)$. The use of lecture method and a media of crossword puzzle about school snacks safety affected the students knowledges in terms of improvement of the selection of healthy snacks.
\end{abstract}

Keywords: Lecture Method, A Media of Crossword puzzle, School Snacks Safety. 


\section{PENDAHULUAN}

Pertumbuhan dan perkembangan seseorang salah satunya dipengaruhi oleh zat gizi yang dikonsumsi sehari-hari. Awal usia 7 tahun anak mulai masuk sekolah, mulai berkenalan dengan suasana dan lingkungan serta kebiasaan baru dalam kehidupannya sehingga mempengaruhi kebiasaan makan anak. Pentingnya mengonsumsi makanan selingan selama disekolah adalah agar kadar gula darah tetap terkontrol dengan baik, sehingga anak tetap konsentrasi terhadap pelajaran dan dapat melaksanakan aktivitas lainnya (FAO, 2009). Berdasarkan laporan akhir hasil monitoring dan verifikasi profil keamanan Pangan Jajanan Anak Sekolah (PJAS) menunjukkan bahwa 98,9\% anak jajan disekolah dan hanya $1 \%$ yang tidak pernah jajan. Data selanjutnya menunjukkan bahwa PJAS menyumbang $31,06 \%$ energi dan $27,44 \%$ protein dari konsumsi pangan harian. PJAS selain sebagai sumber pangan jajanan juga berfungsi sebagai sumber pangan sarapan. (Prasojo, 2012). Di Jawa Timur, Kejadian Luar Biasa (KLB) keracunan makanan masih sangat tinggi. Jumlah kasus keracunan makanan pada tahun 2012 mencapai 1.106 kasus. Pada bulan Februari 2015, terdapat kejadian keracunan masal anak sekolah di 2 Tasikmalaya Jawa Barat dengan korban berjumlah 60 siswa. Mereka keracunan setelah memakan jajanan yang dijual di depan sekolah (Tempo, 2015).

Berdasarkan hasil studi pendahuluan pada tanggal 09 Nopember 2016 di MI Al Hidayah Peterongan Jombang. Penjual kaki lima yang berada diluar sekolah tingkat kebersihannya masih kurang karena tempat/gerobak yang dipakai dalam keadaan kurang bersih dan juga didapati penjual yang masih memakai minyak goreng yang sudah tidak jernih atau sudah dipakai berulang kali dan tidak adanya penyaring untuk menyaring jajanan yang digoreng dengan minyak tersebut, selain itu saos yang digunakan juga warnanya terlalu mencolok. Dari hasil wawancara kepada beberapa siswa, dari 10 anak yang dipilih secara acak, semuanya mengatakan setiap hari membeli jajan di sekolah maupun di luar sekolah. Mereka mengatakan membeli jajan diluar sekolah kalau lagi bosan dengan jajanan yang ada dikantin sekolah. Pengetahuan mereka tentang kebersihan masih kurang karena mereka mengatakan tidak begitu memperhatikan kebersihan dan keamanan jajanan yang dibelinya. Meskipun ada yang pernah mengalami sakit perut dan keracunan makanan setelah membeli jajan secara sembarangan di sekolah.

Berdasarkan hasil penelitian menunjukkan bahwa tingkat pengetahuan gizi PJAS anak sekolah tergolong dalam kategori tinggi namun dalam praktiknya hal ini tidak mendasari pemilihan PJAS yang sesuai oleh anak sekolah, salah satu penyebabnya adalah keterbatasan ketersediaan PJAS yang sesuai di lingkungan sekolah (Tyas, 2013). Menurut (Widodo, 2013) dampak yang bisa dilihat jika anak sekolah mengonsumsi gizi yang tidak seimbang yaitu diantaranya menurunnya konsentrasi belajar siswa, sehingga meningkatkan absensi yang dapat berpengaruh pada prestasi belajar siswa.

Sosialisasi mengenai keamanan pangan dan asupan gizi seimbang yang dibutuhkan oleh anak sekolah dapat dilakukan sebagai upaya promotif untuk meningkatkan status gizi anak sekolah. Orang tua sebagai pihak yang paling bertanggung jawab terhadap kesehatan atau status gizi anak hendaknya dapat mengawasi pola pangan atau jajanan yang pilih oleh anaknya, sehingga dibutuhkan informasi mengenai pangan apa saja yang baik, jajanan yang baik serta dampak yang ditimbulkan apabila anak tidak mengonsumsi pangan dan gizi yang seimbang. Peran guru di sekolah sangat dibutuhkan guna memberikan pendidikan dasar dan pengawasan secara aktif mengenai pangan atau jajanan yang baik dan tidak baik dikonsumsi bisa dengan melakukan pengawasan terhadap penyediaan PJAS di lingkungan sekolah, melakukan edukasi bagi pengelola kantin dan penjaja PJAS serta anak didik (dodik, 2012).

\section{BAHAN DAN METODE}

Penelitian ini menggunakan desain Quasy Experiment, dengan pre-test post-test control group design. Kelompok perlakuan dan 
kelompok kontrol diawali dengan pre-test dan setelah pemberian perlakuan kelompok eksperimen diadakan pengukuran kembali (posttest) (Nursalam, 2015). Populasi penelitian ini populasinya adalah seluruh siswa $\mathrm{MI} \mathrm{Al}$ Hidayah Peterongan dengan jumlah 90 siswa dengan teknik Total Sampling. Variabel independennya adalah penyuluhan kesehatan. variabel dependennya adalah pengetahuan tentang pangan jajanan anak sekolah. Instrument dalam penelitian ini menggunakan kuesioner berbentuk multiple choice. Penelitian ini memakai uji statistik Wilcoxon signed rank test dengan tingkat kemaknaan < 0,05 dan MannWhitney $U$-test dengan tingkat kemaknaan < 0,05 .

\section{HASIL}

a. Tingkat Pengetahuan Siswa Kelompok Perlakuan Dan Kontrol Sebelum Mendapat Penyuluhan

\begin{tabular}{llcccc}
\hline \multirow{2}{*}{ No } & Kategori & \multicolumn{3}{c}{ Penyuluhan Kesehatan } \\
\cline { 3 - 6 } & Pengetahuan & \multicolumn{2}{c}{ (kontrol) } & \multicolumn{2}{c}{ (perlakuan) } \\
\cline { 3 - 6 } & & $\Sigma$ & $\%$ & $\Sigma$ & $\%$ \\
\hline 1 & Baik & 0 & $0 \%$ & 0 & $0 \%$ \\
2 & Cukup & 17 & $37,8 \%$ & 15 & $33,3 \%$ \\
3 & Kurang & 28 & $62,2 \%$ & 30 & $66,7 \%$ \\
\hline & Jumlah & 45 & $100 \%$ & 45 & $100 \%$ \\
\hline
\end{tabular}

Tabel diatas menunjukkan bahwa tingkat pengetahuan siswa sebelum pemberian penyuluhan kesehatan untuk kelompok kontrol 28 responden $(62,2 \%)$ dengan pengetahuan kurang, kelompok perlakuan 30 responden $(66,7 \%)$ pengetahuan kurang.

b. Tingkat Pengetahuan Sesudah Mendapat Penyuluhan Kesehatan

\begin{tabular}{llcccc}
\hline \multirow{2}{*}{ No } & Kategori & \multicolumn{3}{c}{ Penyuluhan Kesehatan } \\
\cline { 3 - 6 } & Pengetahuan & \multicolumn{2}{c}{ (kontrol) } & \multicolumn{3}{c}{ (perlakuan) } \\
\cline { 3 - 6 } & & $\Sigma$ & $\%$ & $\Sigma$ & $\%$ \\
\hline 1 & Baik & 30 & $66,7 \%$ & 39 & $86,7 \%$ \\
2 & Cukup & 15 & $33,3 \%$ & 6 & $13,3 \%$ \\
3 & Kurang & 0 & $0 \%$ & 0 & $0 \%$ \\
\hline & Jumlah & 45 & $100 \%$ & 55 & $100 \%$ \\
\hline
\end{tabular}

Tabel diatas menunjukkan bahwa tingkat pengetahuan siswa sesudah diberikan penyuluhan kesehatan kelompok kontrol sebanyak 30 responden $(66,7 \%)$ pengetahuan baik dan kelompok perlakuan sebanyak 39 responden $(86,7 \%)$ pengetahuan baik.

c. Analisis Pengaruh Penyuluhan Kesehatan Terhadap Tingkat Pengetahuan Siswa Tentang Pangan Jajanan Anak Sekolah.

Hasil uji Wilcoxon (Wilcoxon signed ranks test) diperoleh sig $=0,000<0,05$, bahwa Ho ditolak dan $\mathrm{H} 1$ diterima, berarti ada pengaruh penyuluhan kesehatan terhadap pengetahuan siswa tentang pangan jajanan anak sekolah.

d. Analisis Perbedaan Kelompok Perlakuan Dan Kelompok Kontrol Sesudah penyuluhan Kesehatan Terhadap Pengetahuan Siswa Tentang Pangan Jajanan Anak Sekolah.

Hasil analisis uji Mann-Whitney U (Mann-Whitney U-test) didapatkan sig = $0,000<0,05$, bahwa Ho ditolak dan H1 diterima, berarti ada perbedaan kelompok perlakuan dan kelompok kontrol sesudah pemberian penyuluhan kesehatan terhadap pengetahuan siswa tentang pangan jajanan anak sekolah.

\section{PEMBAHASAN}

a. Pengetahuan Sebelum Penyuluhan Kesehatan Berdasarkan Tabel diatas didapatkan bahwa pengetahuan sebelum penyuluhan kesehatan untuk kelompok kontrol kelompok kontrol 28 responden $(62,2 \%)$ dengan pengetahuan kurang, kelompok perlakuan 30 responden $(66,7 \%)$ pengetahuan kurang.

Kurangnya pengetahuan ini kemungkinan dipengaruhi oleh beberapa faktor yang mempengaruhi tingkat pengetahuan seperti umur, sumber informasi dan pengalaman menerima informasi. Hal ini dapat dilihat dari karakteristik responden berdasarkan umur bahwa usia untuk kelompok kontrol hampir setengahnya berumur 11 tahun sebanyak 21 responden (38\%) dan sebagian kecil berumur 8 dan 13 tahun sebanyak masing-masing 1 responden (1\%). Untuk kelompok perlakuan hampir setengahnya juga berumur 11 tahun sebanyak 
23 responden (42\%) dan sebagian kecil berumur 12 tahun sebanyak 3 responden (5\%). Data tersebut membuktikan bahwa usia berpengaruh terhadap daya tangkap dan pola pikir seseorang, sehingga semakin dewasa seseorang maka pengetahuan yang diperolehnya semakin membaik.

Karakteristik responden berdasarkan sumber informasi diperoleh bahwa kelompok kontrol hampir setengahnya tidak pernah mendapat informasi yaitu 26 responden (47\%), sedangkan sebagian kecil responden memperoleh informasi dari keluarga sebanyak 3 responden (6\%). Keterangan diatas menunjukkan bahwa masih banyak siswa yang belum pernah mendapat informasi sama sekali baik dari lingkungan sekolah, internet, majalah, brosur ataupun media massa. Seharusnya keluarga adalah orang yang nomor satu dalam memberikan pendidikan kepada anaknya untuk berperilaku hidup sehat. Untuk kelompok perlakuan hampir setengahnya juga tidak pernah mendapat informasi sebanyak 27 responden $(49 \%)$, sedangkan sebagian kecil responden mendapat informasi dari petugas kesehatan yaitu 2 responden (4\%). Keterangan diatas menunjukkan bahwa masih banyak siswa yang belum pernah mendapat informasi sama sekali. Dan alangkah baiknya di sekolahan sering diadakan promosi kesehatan baik dari petugas kesehatan maupun dari pihak sekolahan sehingga siswa bias mengetahui informasi-informasi tentang kesehatan khususnya keamanan jajanan sekolah yang setiap hari dikonsumsi oleh siswa.

Karakteristik responden berdasarkan pengalaman menerima informasi pada kelompok kontrol diperoleh bahwa hampir setengahnya sebanyak 26 responden (47\%) tidak pernah menerima informasi sama sekali, sedangkan sebagian kecil pengalaman menerima informasi 1 bulan sekali sebanyak 2 responden (4\%). Sedangkan untuk kelompok perlakuan diperoleh bahwa hampir setengahnya juga tidak pernah menerima informasi sebanyak 27 responden (49\%), sedangkan sebagian kecil pengalaman menerima informasi 1 bulan sekali sebanyak
5 responden (9\%). Keterangan tersebut menunjukkan bahwa pengalaman adalah sumber pengetahuan yang sangat berpengaruh terhadap pengetahuan seseorang.

Pengetahuan siswa mengenai keamanan jajanan sekolah sangat penting karena masih banyak jajanan sekolah yang komposisinya ada Bahan Tambahan Pangan (BTP) yang dapat mempengaruhi fungsi otak termasuk gangguan konsentrasi sehingga berdampak pada prestasi belajar siswa.

b. Pengetahuan Sesudah Penyuluhan Kesehatan

Berdasarkan Tabel diatas menunjukan bahwa pengetahuan siswa sesudah pemberian promosi kesehatan menggunakan metode ceramah (kelompok kontrol) sebagian besar yaitu sebanyak 40 responden $(73 \%)$ dalam kategori pengetahuan baik, dan hampir setengahnya sebanyak 15 responden (27\%) dalam kategori pengetahuan cukup. Sedangkan untuk metode ceramah dan media teka-teki silang (kelompok perlakuan) hamper seluruhnya yaitu sebanyak 49 responden (89\%) dalam kategori pengetahuan baik, dan sebagian kecil yaitu 6 responden (11\%) dalam kategori pengetahuan cukup.

Rata-rata nilai responden mengalami peningkatan sesudah diberikan penyuluhan kesehatan tentang pangan jajanan anak sekolah meskipun masih ada dalam kategori cukup, hal ini terjadi karena ada beberapa factor yang mempengaruhi diantaranya adalah informasi. Informasi yang diperoleh dari pendidikan formal maupun nonformal, contohnya dari keluarga, guru, petugas kesehatan melalui penyuluhan kesehatan seperti yang dilakukan dalam penelitian ini.

Menurut (Notoatmodjo, 2012) bahwa penyuluhan kesehatan merupakan kegiatan yang direncanakan yang bertujuan untuk mempengaruhi orang lain. Orang lain yang dimaksud adalah individu, kelompok, atau masyarakat. Hasil yang diinginkan dari penyuluhan atau pendidikan kesehatan adanya perubahan perilaku kesehatan.

Menurut (Supiyati, 2012) bahwa ada beberapa faktor yang kemungkinan dapat 
mempengaruhi penyuluhan kesehatan diantaranya adalah pemateri, materi, media, penyuluhan, serta sasaran. Sejalan dengan Lawrence Green bahwa yang mempengaruhi perilaku ada dua faktor yaitu sikap dan lingkungan sekitar.

c. Analisis Pengaruh Penyuluhan Kesehatan Terhadap Pengetahuan Siswa Tentang Pangan Jajanan Anak Sekolah

Berdasarkan Tabel diatas dapat diketahui hasil analisis uji peringkat bertanda Wilcoxon dapat diketahui bahwa $\rho=0,000$ artinya $\rho<0,05$. Hasil uji tersebut yang berarti ada pengaruh penyuluhan kesehatan terhadap pengetahuan siswa tentang pangan jajanan anak sekolah di MI Al Hidayat Peterongan Jombang.

Beberapa factor yang mempengaruhi dalam memilih metode dan media penyuluhan kesehatan diantaranya karakteristik sasaran meliputi jumlah dan umur, waktu penyuluhan, tempat, serta tujuan yang diinginkan.

Metode ceramah dalam penyuluhan merupakan cara yang paling efektif untuk pendekatan terhadap suatu kelompok, dimana metode ini akan mempermudah terjadinya trust antara pemateri dan sasaran sehingga tujuan yang diinginkan mudah tercapai (Notoatmodjo, 2012).

Otak mahir dan sangat senang mengambil informasi acak dan kacau lalu mentertibkannya. Otak bila dimungkinkan untuk mengekspresikan perilaku membentuk polanya, menciptakan koherensi dan makna (Mubarak, 2011). Desain yang sama dapat juga digunakan pada tujuan yang berbeda, permainan seperti teka-teki silang, bingo, dan kartu bergambar dapat menjadi simulasi pembelajaran kooperatif dan kompetitif yang digunakan sebagai pendekatan atau strategi pembelajaran. Penjelasan tersebut merujuk bahwa teka-teki silang menumbuhkan keaktifan siswa karena pembelajaran terpusat pada siswa. Diharapkan siswa dapat belajar dengan apa yang mereka kerjakan sehingga kognitifnya berjalan. d. Analisis Perbedaan antara Kelompok Perlakuan Dan Kelompok Kontrol Sesudah Penyuluhan Kesehatan Terhadap Pengetahuan Siswa Tentang Pangan Jajanan Anak Sekolah

Hasil Uji Mann-Whitney bahwa $\rho=0,000$ artinya $\rho<0,05$. Berarti Ho ditolak dan $\mathrm{H} 1$ diterima, bahwa ada perbedaan antara kelompok eksperimen dan kelompok kontrol tentang pengaruh penyuluhan kesehatan terhadap pengetahuan siswa tentang pangan jajanan anak sekolah di MI Al Hidayah Peterongan Jombang.

Penyuluhan kesehatan merupakan salah satu upaya untuk meningkatkan pengetahuan tentang kesehatan sehingga tercapai derajat kesehatan yang optimal. Belajar merupakan suatu kegiatan yang harus dilakukan secara berulang-ulang serta didasari oleh kesadaran dan rasa ingin tahu terhadap sesuatu hal-hal yang dianggap baru.

Menurut Bloom dikutip dari (Notoatmodjo, 2012), menyebutkan bahwa jika seseorang telah mengetahui adanya stimulus atau rangsangan tentang pengetahuan, maka selanjutnya seseorang tersebut akan melakukan suatu penilaian atau berpendapat terhadap apa yang diketahuinya, berikutnya dengan harapan seseorang tersebut akan melakukan atau mempraktekkan apa yang telah diketahuinya. Hal tersebut yang dikatakan mengaplikasikan (application) atau praktek (practice) tentang kesehatan, atau dapat juga disebut perilaku sehat (overt behaviour).

\section{SIMPULAN}

Pemberian penyuluhan kesehatan berpengaruh terhadap pengetahuan siswa tentang pangan jajanan anak sekolah.

\section{SARAN}

\section{a. Bagi Profesi Keperawatan}

Perlu adanya intervensi keperawatan berfokus pada pangan jajanan anak sekolah sekolah serta memperhatikan lingkungan tempat jajanan yang masih kurang higinis.

\section{b. Bagi Instansi}


Sebagai masukan untuk instansi kesehatan dalam upaya program promosi kesehatan dengan penyuluhan kesehatan yang cocok untuk menambah pengetahuan anak usia sekolah dasar.

\section{c. Bagi Peneliti Selanjutnya}

Memberikan masukan kepada peneliti selanjutnya untuk meningkatkan desain penelitian (Quasy Experiment atau True Experiment), dan menciptakan metode baru dalam promosi kesehatan dengan responden yang berbeda. Seperti mencari metode permainan lain untuk ruang lingkup anak usia sekolah.

\section{DAFTAR PUSTAKA}

FAO, 2009. Ensuring Quality Street Food. [Online] Available at: HYPERLINK "Ftp://ftp.fao.org/" Ftp://ftp.fao.org/ [Accessed 8 Nopember 2017].

Judarwanto, 2014. Perilaku Makan Anak Sekolah. [Online] Available at: HYPERLINK "http//:gizi.depkes.go.id/" http//:gizi.depkes.go.id/ [Accessed 10 Pebruari 2017].

Kementrian Kesehatan RI., 2011. Pangan Jajanan Anak Sekolah (PJAS). Jakarta: Jejaring Informasi Pangan dan Gizi.
Mubarak, 2011. Promosi Kesehatan untuk Kebidanan. Jakarta: Salemba Medika.

Notoatmodjo, S., 2012. Promosi Kesehatan di Sekolah. Jakarta: Rineka Cipta.

Nursalam, 2015. Metodologi Penelitian Ilmu Keperawatan Pendekatan Praktis. Jakarta: Salemba Medika.

Supiyati, 2012. Promosi Kesehatan dalam Perspektif Ilmu Kebidanan. Yogyakarta: Pustaka Rihama.

Tempo, C., 2015. 60 Siswa SD di Tasikmalaya Keracunan Jajanan. [Online] Available at: HYPERLINK "http//:m.tempo.co" http//:m.tempo.co [Accessed 5 Pebruari 2017].

Tyas, S.E.S., 2013. Gambaran Perilaku Jajan Murid Sekolah Dasar. Psikobuana, Volume 1.

Widodo, 2013. Perilaku Makan Anak Sekolah (Serial Online). [Online] Available at: HYPERLINK "http//:www.repository.unhas.ac.id" http//:www.repository.unhas.ac.id [Accessed 8 Nopember 2016]. 